\title{
Innovation without Change?
}


Also by David Brandon

Zen in the Art of Helping

Human Being Human

The Survivors

The Trick of Being Ordinary

Consumers as Colleagues

Putting People First 


\title{
Innovation without Change?
}

Consumer Power in Psychiatric Services

\author{
David Brandon
}

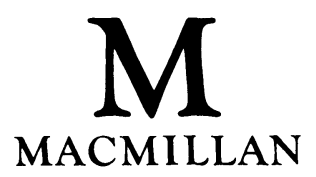


All rights reserved. No reproduction, copy or transmission of this publication may be made without written permission.

No paragraph of this publication may be reproduced, copied or transmitted save with written permission or in accordance with the provisions of the Copyright, Designs and Patents Act 1988, or under the terms of any licence permitting limited copying issued by the Copyright Licensing Agency, 33-4 Alfred Place, London WC1E 7DP.

Any person who does any unauthorised act in relation to this publication may be liable to criminal prosecution and civil claims for damages.

First published 1991

Published by

MACMILLAN EDUCATION LTD

Houndmills, Basingstoke, Hampshire RG21 2XS

and London

Companies and representatives

throughout the world

Edited and typeset by Povey/Edmondson

Okehampton and Rochdale, England

British Library Cataloguing in Publication Data Brandon, David 1941-

Innovation without change?: consumer power in psychiatric services.

1. Mentally ill persons. Care

I. Title

362.20425

ISBN 978-0-333-48824-9

ISBN 978-1-349-21361-0 (eBook)

DOI 10.1007/978-1-349-21361-0 
This book is dedicated to the memory of John Perceval, founder of the Alleged Lunatics Friends Society in 1845 and great grandfather of the English mental illness service reform movements 


\section{Contents}

Acknowledgements viii

1 Introduction 1

2 Lunatics and Asylums 7

3 Winds and Tides 32

4 Match or Mismatch? 55

5 Telling People Much Much More 77

6 Adventurous Listening 98

7 Speaking Out 116

8 Democracy in Strange Places 143

9 Innovation without Change? 164

$\begin{array}{ll}\text { Index } & 175\end{array}$ 


\section{Acknowledgements}

I owe many thanks to Malcolm Rae, psychiatric nurse and Prestonian par excellence; Lindsey Dyer, long-time friend and Director of North West MIND; Shula Ramon, Peter Campbell, Ingrid Barker, Jan Wallcraft, Peter Beresford, Suzy Croft, Edith Morgan and Wout Hardeman from Holland.

I owe much love to my wife Althea for all her support.

It is none of these people's fault that this book is not much much better.

DAVID BRANDON 